\title{
TŘETÍ KONFERENCE AKTUÁLNÍ TRENDY V MUZEJNII PREZENTACI A EDUKACI
}

\author{
IVA VACHKOVÁ
}

https://doi.org/10.5817/MuB2019-2-10

Západočeské muzeum v Plzni hostilo ve dnech 3.-4. 6. 2019 zejména muzejní pedagogy z celé republiky. Nechyběli ani pracovníci zajištující komunikaci s veřejností a muzejní aktivity pro ni. Komise pro práci $s$ veřejností a muzejní pedagogiku při AMG připravila skutečně nabitý a zajímavý program. Podtitul konference Neobyčejné možnosti neformálního vzdělávání naznačil, že se jednání dotkne zejména novinek ve vzdělávání v muzeu. První jednací den byl zaměřen na propojování formálního a neformálního vzdělávání, druhý pak na neobyčejné možnosti muzejní edukace.

Konferenci slavnostně zahájil náměstek ministra kultury pro řízení Sekce kulturního dědictví Ing. Vlastislav Ouroda, Ph.D. Na něj navázal primátor města Plzně Mgr. Martin Baxa, poslední uvítací proslov pronesl ředitel Západočeského muzea v Plzni PhDr. František Frýda. Př́ijemným oživením bylo představení elektronického hlídače dodržování délky konferenčních příspěvků v podobě 3D busty J. A. Komenského.

Dva hlavní příspěvky potvrdily už výběrem referentů téma dne. Formální vzdělávání zastupoval doc. PhDr. Jan Hábl, Ph.D. z Katedry pedagogiky a psychologie Univerzity Hradec Králové. Ve svém příspěvku Je možné naučit dobru? definoval pojetí dobra $\mathrm{z}$ ontologického i morálního hlediska a naznačil směry, kterými se může formální vzdělávání ubírat, aby byl rozvíjen potenciál vzdělávaných osob. Neopomněl ani připomenout, jak tyto otázky byly v minulosti

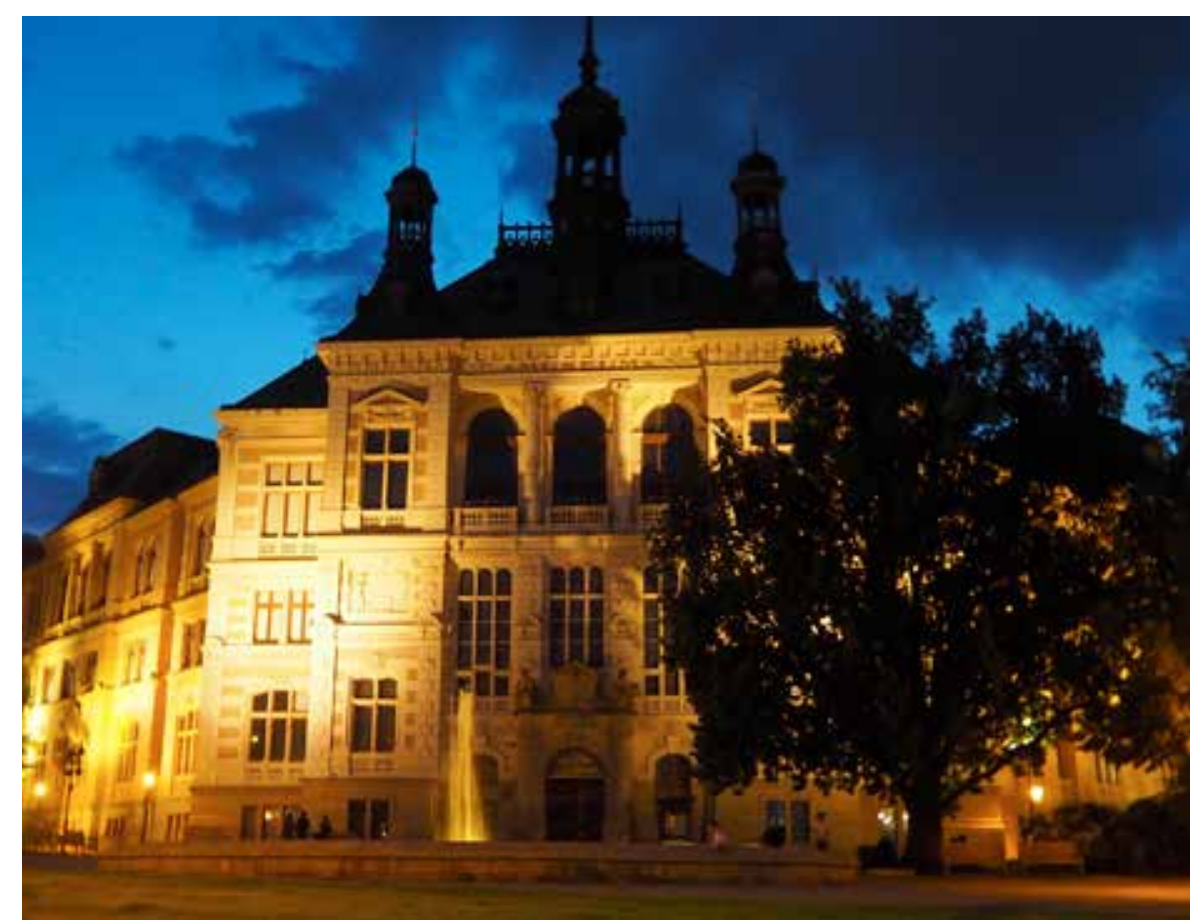

Obr. 1: Západočeské muzeum v Plzni (foto: Michaela Zálešáková).

řešeny různými filozofy a vzdělavateli. Neformální vzdělávání zastupoval Bob Kartous z informačního centra o vzdělávání EDUin o. p. s. Jeho příspěvek nazvaný Což takhle nevzdělávat se jeden den $v$ týdnu ve škole? se proměnil spíše v burzu různých př́íkladů dobré praxe $v$ této oblasti od Jihlavy a Humpolce po Prahu bez širšího kontextuálního začlenění.

Tři zahraniční přednášky byly simultánně tlumočeny do češtiny. Matija Dronjić z Etnografického muzea Zagreb se zabýval možnostmi muzealizace nehmotného kulturního dědictví na příkladu zapojení místní komunity obce Lepoglava na přípravě výstavy o umění krajkářství, a to včetně vedení workshopů při př́ležitosti výstavy. Mimo jiné vyslovil i hypotézu, že motivovaná místní komunita může zapojovat návštěvníky muzea úspěšněji do muzejních aktivit při výstavě než muzejní profesionál. Željka Bosnar Salihagić, ředitelka Tyflografického muzea Zagreb, představila koncept práce muzea zaměřeného na návštěvníky se speciálními potřebami. Zmínila i řadu opatření, zejména pro slabozraké a nevidomé návštěvníky, a její praktické rady ohledně typu prùvodců, grafické prvky či webové prezentace pro tento typ návštěvníků se setkaly s velkým ohlasem. Zřejmě také proto, že systematická práce $\mathrm{v}$ této oblasti není $\mathrm{v}$ našich muzeích ještě dostatečně zavedena. Tjaša Juhart z Muzea loutkářství 


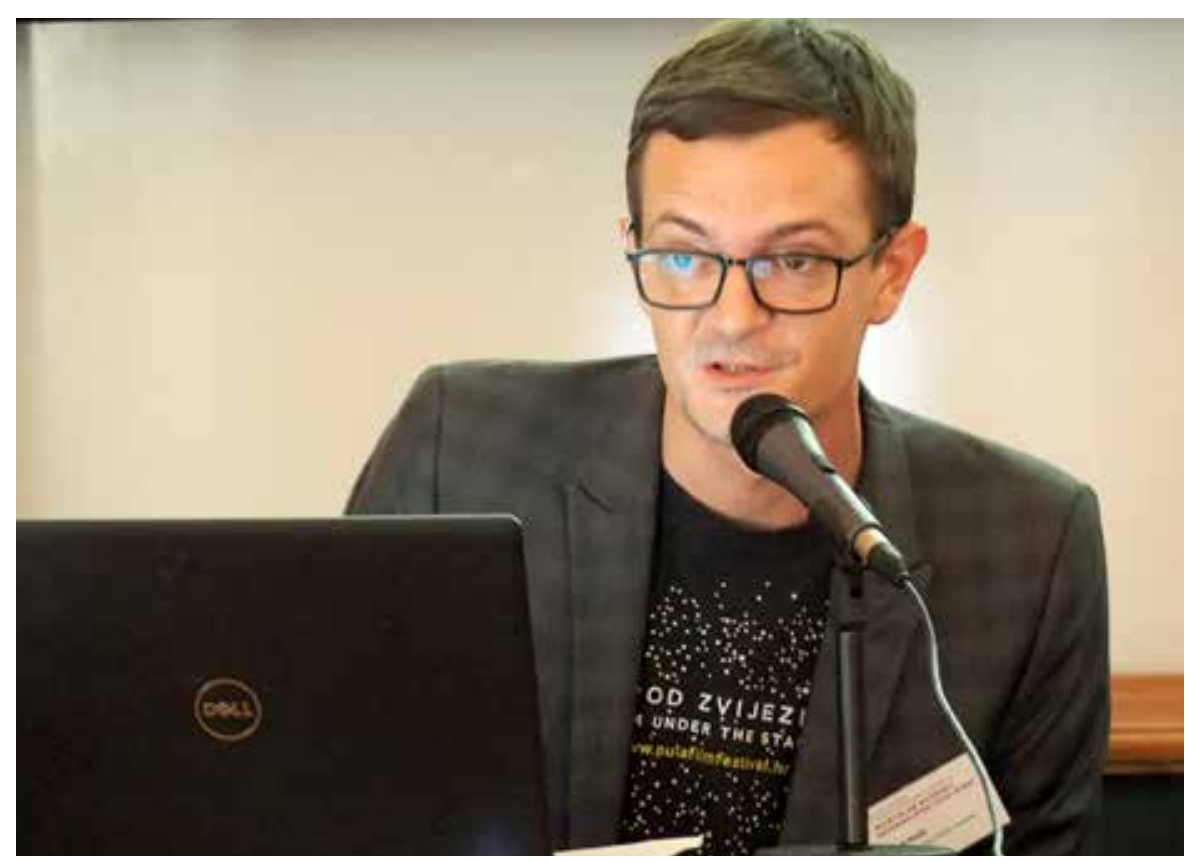

Obr. 2: Přednášející Matija Dronjić z Etnografického muzea v Zagrebu (foto: Michaela Zálešáková).

Ljubljana představila koncept vzdělávání v jednom ze specifických typů muzeí a dokumentovala ho na řadě konkrétních příkladů. Její vystoupení bylo zajímavé pro všechny, ale určitě i inspirativní pro pracovníky našich loutkářských muzeí, at̉ už v Brně, Chrudimi, Praze, Prachaticích či Plzni.

Odpoledne prvního dne konference patřilo prezentacím ve formátu Pecha Kucha, které představovaly mezinárodní a meziinstitucionální projekty v muzejní edukaci. Cílem tohoto typu prezentace je co nejhutněji v krátkém čase představit nějaký projekt. $\mathrm{V}$ původním prostředí architektů jsou prezentace založené na obrazové dokumentaci (max. 20 obrázků), kdy každý obrázek je možné komentovat 20 s. Pro muzejní potřeby se používá nejčastěji 10 minutový časový formát a počet komentovaných „obrázků“ nebývá omezen. V rychlém sledu tak návštěvníci dostali informace o projektu Artcome/Na vlnách tvořivosti a mezinárodní spolupráce (Mgr. Terezie Čermáková a Mgr. Jana Macháčková, Muzeum umění Olomouc), Interpretace „O páté...“/
Neformální inspirace z Velké Británie (Barbora Dvořáková, členka Sdružení pro interpretaci místního dědictví a Interpret Europe), Společně do muzea (Bc. Tomáš Pruner, Oddělení celoživotního vzdělávání Západočeského muzea v Plzni), Kontaktní a př́běhové programy bez pracovních listů a nové formy spolupráce napříč institucemi (Mgr. Silvie Čermáková, Muzeum Vysočiny Jihlava), Hranice formálního a neformálního vzdělávání (Mgr. Jakub Halaš, Mgr. Petra Skřivánková, Mgr. Adéla Vernerová - všichni Muzeum Říčany) a Zprostředkování kulturního dědictví např́č muzejní, galerijní a památkovou edukací (Mgr. Jitka Petřeková, NPÚ). Z šesti konkrétních prríkladi̊ projektů lze vyvodit několik obecnějších tvrzení: v poslední době dochází k propojování nejrůznějších institucí, jejichž činnost si klade také vzdělávací cíle; ačkoliv naše školy vzdělávají často „solitéry“ v konkurenčním prostředí, budoucnost neformálního vzdělávání je v komunitním životě a kooperaci např́ič institucemi, radnicemi a spolky; je-li adresátem neformálního vzdělávání dítě, je třeba se přizpůsobit jeho potřebám a myslet i na místa k odpočinku; muzea jsou vhodným prostředím pro neformální badatelskou výuku, protože disponují vhodným pramenným materiálem; je třeba revidovat přípravu pracovních listů a také práci s nimi a připustit, že vzdělávat neformálně lze i bez nich a stejně tak se i zamýšlet více nad muzejními kufř́íky, které se postupně namísto schránky na pomůcky stávají nabídkou historických pramenů; doba přeje více práci týmů než jednotlivců, v týmu zvládneme více a lépe.

V podvečer se také v Národopisném muzeu Plzeňska sešli členové Komise pro práci s veřejností a muzejní pedagogiku na otevřeném plenárním a volebním zasedání, po němž následovalo neformální setkání v kreativním plzeňském prostoru DEPO2015.

Druhý jednací den byl rozdělen na tři prezentační bloky praktických zkušeností po 15 minutách a závěrečnou panelovou diskusi o podpoře talentovaných dětí v muzeích. První blok představoval možnosti práce s obtížnými (zejména emocionálně zatíženými) tématy a „nové“ publikum v muzejní edukaci. Zazněly příspěvky Místa paměti: Úvaha o vzděláváni o holocaustu v muzejním prostředí (Mgr. et Mgr. Veronika Kolaříková, Muzeum romské kultury Brno), Vím, co se stalo: Interdisciplinární výuka s využitím studentského vyučování (Mgr. Denisa Glacová a Bc. Martina Kutková, Židovské muzeum Praha), Muzeum v nemocnici, muzeum na cestě (Mgr. Simona Šindelářová), Potenciál muzejní edukace pro osoby $s$ Alzheimerovou chorobou (Věra Pinnoy, GASK Kutná Hora) a Ano, pane doktore... experiment $3 v 1$ - první pomoc, zdravý životní styl a zdravotnictví v současné i prvorepublikové praxi jako téma sociálně preventivního projektu $v$ muzejním prostředí (Mgr. Jitka Králová, Regionální muzeum Mělník). Tyto příspěvky byly různorodé, zobecňovat nad 


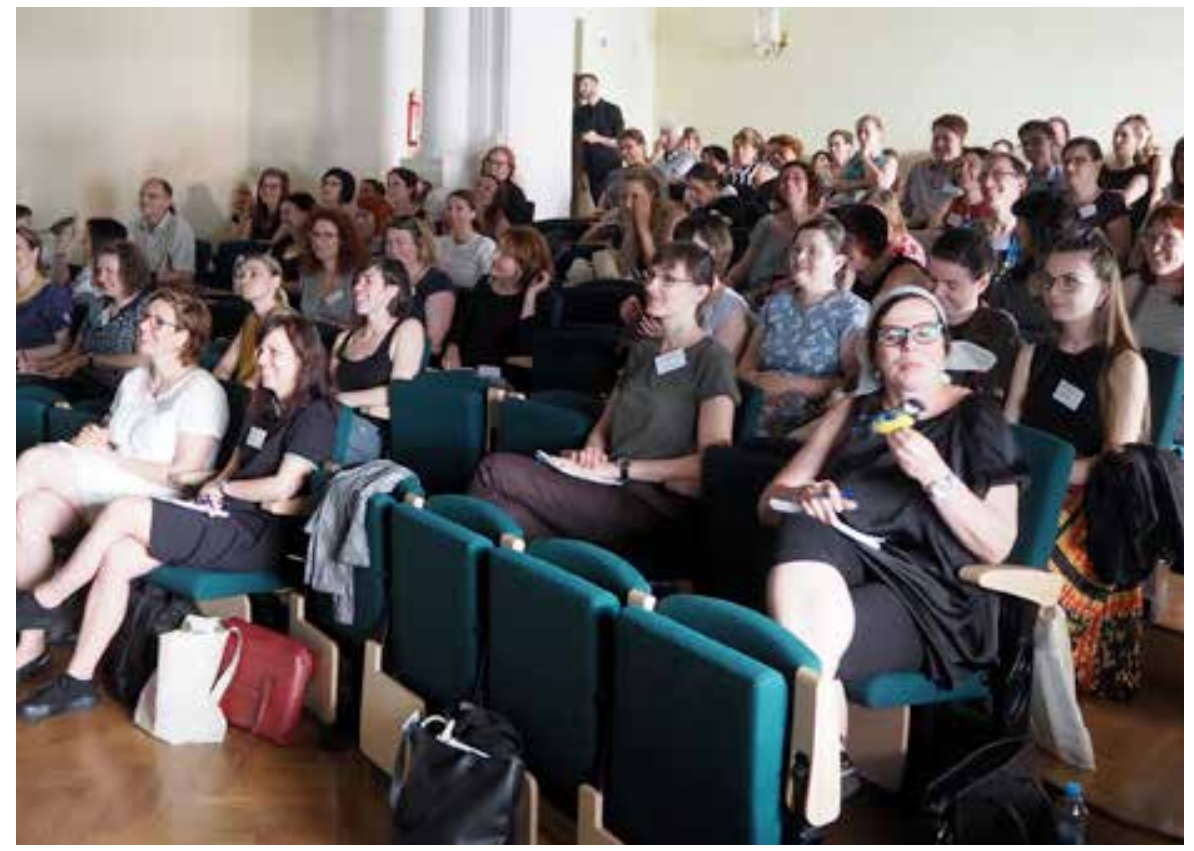

Obr. 3: Pohled do sálu Západočeského muzea v Plzni na účastníky konference (foto: Michaela Zálešáková).

nimi př́liš nelze. Snad je ale možné podotknout, že metodika výuky o šoa ve školním prostředí je velmi propracovaná a má u nás více než dvacetiletou tradici zejména díky systematickému vzdělávání učitelů vzdělávacím oddělením Památníku Terezín a také práci lektorů Židovského muzea v Praze. Tyto zkušenosti je možné obdobně využít i pro vzdělávání o romském holocaustu. Inovativní je spolupráce Gymnázia Přírodní škola (která také není v oboru nováčkem, ale osvědčeným frontmanem a v mnohém vzorem) a Židovského muzea v Praze na studentském vyučování, tady je obrovský potenciál pro školní i neformální vzdělávání. Rozšiřování muzejní klientely spojuje další dva příspěvky, práce se seniory a nemocnými dětmi je záslužná a potřebná a nutí $\mathrm{k}$ hledání nových cest. Možnost zapojení do širší prevence sociálně patologických jevů formou meziinstitucionálních projektů je cesta zejména pro menší regionální muzea a inspirace Mělníkem může být nakažlivá.

Další dva bloky přinesly celkem 12 různorodých příspěvků. Zde je jejich přehled: Šifrované hry $v \mathrm{Mu}$ zeu Blanenska (Mgr. Daniela Pernesová, Mgr. Bc. Pavlína Komínková, Muzeum Blanenska), Únikovka, ano či ne?: Zpracování 30 let od sametové revoluce (Miroslava Brůnová, DiS., Oblastní muzeum Chomutov), Prahou za prírodou - projekt občanské vědy (Mgr. Monika Stránská, Ing. Petra Caltová, Národní muzeum Praha), Pípáci a tajní agenti: Edukační program $k$ ornitologické expozici „Památník Karla Plachetky“ (Mgr. Martina Marxová), Náš streetart (Mgr. Pavlína Pitrová, Oblastní galerie Vysočiny Jihlava), Secretár̆ - když se obyčejné věci stávají neobyčejnými (Mgr. Barbora Škaloudová a Mgr. Ida Muráňová, Národní galerie Praha), Interaktivní studia (Mgr. et MgA. Oldřich Bystřický, Mgr. Hana Dočkalová, Národní galerie Praha), Možnosti neformálního vzdělávání $v$ hornickém muzeu Př́bram (PhDr. Pavla Trantinová Žvachtová, Mgr. et Mgr. Stanislava Moravcová, Hornické muzeum Příbram), Nafilm: Národní filmové muzeum (Jakub Jiřrště, Terezie Křížkovská, Adéla Mrázová, Národní filmové muzeum Praha), Aby muzeum nebyla nuda (Martina Sed- láková, Zámek Ždár nad Sázavou), Vzdělávání mezi kořeny (RNDr. Sylvie Pecháčková, Ph.D., Západočeské muzeum Plzeň), Mohou mít muzea zásadní roli v procesu inkluze? (Mgr. Světlana Drábová). V přednesených příspěvcích si účastníci konference našli celou řadu zajímavých nápadů, postřehů a příkladi̊ hodných následování. Snahy o zlepšení edukace $\mathrm{v}$ muzeích vedou muzea k experimentům, $\mathrm{k}$,vystrkování růžků “ $\mathrm{z}$ muzea ven, ke komunitním a interdisciplinárním spolupracím, k větší popularizaci. Svého času jsme s přáteli mluvili o tzv. hejkalizaci památek, o nekritickém přebírání líbivých kostýmů, pseudohistorických rekvizit a o tom, že návštěvník památek možná nepotřebuje kostýmovaného průvodce, ale někoho, kdo ho nasměruje $\mathrm{k}$ tomu důležitému, co může obohatit jeho svět. Na konferenci v Plzni se mi to nestalo, ale poměrně často čelím nápadi̊m „hejkalizovat“ muzeum ve snaze „přiblížit se publiku“. Když jsem se probírala programem plzeňské konference muzejních edukátorů, hledala jsem, co je to nejdůležitější, co chceme (at už formálně ve školách či neformálně v muzeích) předávat. Odpověděl mi na to příspěvek Vzdělávání mezi kořeny, kdy Sylvie Pecháčková s nadšením mluvila o přípravách botanické výstavy o kořenech. O tom, co sama při práci na koncepci výstavy objevila, co jí ukázali dobrovolníci, senioři, studenti, žáci. A také o tom, co chtěla říct ona jako muzejní botanik. Dokázala současně vykročit $\mathrm{z}$ muzea ven a zároveň $\mathrm{v}$ něm zůstat a využít jeho přirozený potenciál a individualitu. A to je také to, co bychom ve své další práci měli chtít. Zůstávat doma (u muzejních cílů a specifik) a zároveň jít ven (inspirovat se, poznávat a spolupracovat).

Poslední částí programu byla panelová diskuse. Součástí pracovišt́ NIDV je také Talentcentrum, oddělení zaměřené na práci s talentovanými dětmi. To připravilo projekt 
T-praxí, zaměřených na zapojování žáků do práce muzeí. Vlastivědné muzeum Jesenicka, na diskusi zastoupené ředitelem Mgr. Pavlem Rušarem a archeologem Mgr. Milanem Rychlým, přizvalo $\mathrm{k}$ přípravě výstavy žáky jako partnery a zapojilo je do všech činností (diskutoval absolvent T-praxe Marek Pallys, žák Gymnázia a střední odborné školy v Rýmařově a učitelka ZŠ Jeseník Mgr. Světluše Smékalová). Širší kontext T-praxe přišli ozřejmit ze strany NIDV RNDr. Stanislav Zelenda (pracovník systémové podpory nadání) a ze strany škol Mgr. Hana Stýblová (prezidentka asociace ředitelů ZŠ). Cílem panelové dis- kuse bylo představit tento projekt a umožnit plénu se dotazovat př́mo realizátorů a podporovatelů projektu. Publikum se tak seznámilo s tím, že žáci pracují na koncepci výstavy, realizují badatelskou aktivitu na její téma, navrhují sbírkové předměty a archiválie do chystané výstavy, spolupracují na propagaci, realizují doprovodné programy a sami také výstavu zahajují. Dotazy z publika otevřely i otázku financování a podpory z NIDV, spolupráci se školou, z níž je žák zapojený do práce na výstavě a také nutné zázemí muzea pro takovou práci. Největším úspěchem této diskuse by bylo, kdyby se některé z regionálních muzeí rozhodlo projekt T-praxe realizovat ve vlastním pracovišti a s místní školou.

Při zakončení konference došlo i na upřímné poděkování hostující instituci, Západočeskému muzeu v Plzni, členům Komise pro práci s veřejností a muzejní pedagogiku AMG a zejména hlavní organizátorce Mgr. Denise Brejchové.

\section{IVA VACHKOVÁ}

Muzeum hlavního města Prahy, Česká republika 